NBER WORKING PAPER SERIES

\title{
FINANCIAL LITERACY, INFORMATION, AND DEMAND ELASTICITY: SURVEY AND EXPERIMENTAL EVIDENCE FROM MEXICO
}

\author{
Justine S. Hastings \\ Lydia Tejeda-Ashton \\ Working Paper 14538 \\ http://www.nber.org/papers/w14538
NATIONAL BUREAU OF ECONOMIC RESEARCH
1050 Massachusetts Avenue
Cambridge, MA 02138 \\ December 2008
}

We thank Joseph Altonji, Daniel Benjamin, Jeffrey Brown, Donald Green, Dean Karlan, Jeffrey Kling, Annamaria Lusardi, Olivia Mitchell, Paul Schultz, Robert Willis, and seminar participants at Yale University, the University of Illinois and the NBER Program on Aging for valuable comments. We also thank the excellent staff at CONSAR for assistance with this project. We gratefully acknowledge financial support from the Yale University Institution for Social and Policy Studies. The views expressed herein are those of the author(s) and do not necessarily reflect the views of the National Bureau of Economic Research.

NBER working papers are circulated for discussion and comment purposes. They have not been peerreviewed or been subject to the review by the NBER Board of Directors that accompanies official NBER publications.

(C) 2008 by Justine S. Hastings and Lydia Tejeda-Ashton. All rights reserved. Short sections of text, not to exceed two paragraphs, may be quoted without explicit permission provided that full credit, including (๑) notice, is given to the source. 
Financial Literacy, Information, and Demand Elasticity: Survey and Experimental Evidence from Mexico

Justine S. Hastings and Lydia Tejeda-Ashton

NBER Working Paper No. 14538

December 2008

JEL No. H0,H55,L10

\begin{abstract}
We use responses to a survey and experiment with participants in Mexico's privatized social security system to examine how financial literacy impacts workers' choice behavior and how simplifying information on management fees may increase measures of price elasticity sensitivity among the financially illiterate. We find that by presenting fees in pesos instead of annual percentage rates, financially illiterate workers focus much more on fees when choosing between investment funds, selecting funds with lower average fees in hypothetical choice settings. Even though changes in information have small impacts on fees of the selected fund, holding fees constant, we show that changes in choice behavior imply a substantial increase in price sensitivity. Hence, the way in which information is presented to workers can have a substantial impact on optimal fees that firms can charge in the marketplace.
\end{abstract}

Justine S. Hastings

Yale University

P.O. Box 208264

New Haven, CT 06520-8264

and NBER

justine.hastings@yale.edu

Lydia Tejeda-Ashton

207 Giannini Hall \#3310

University of California

Berkeley, CA 94720-33

lashton@are.berkeley.edu 


\section{Introduction}

Policy reforms are increasingly incorporating expanded consumer choice and privatization in an effort to increase efficiency and consumer welfare in traditionally publicly provided markets. This movement towards increased choice and privatization has affected policy reforms in public education (No Child Left Behind, school choice, and charter schools), public healthcare (Medicare part D), and social security. Social security reform is a particularly pressing issue as economies around the world grapple with aging populations and longer life expectancy. One goal of replacing pay-as-you-go systems with fully funded private account plans is to increase expected retirement wealth for a given level of contributions, through market-driven efficiency gains (Geanakoplos, Mitchell, and Zeldes [1998], Feldstein and Samwick [1999], Feldstein and Liebman [2001]). However, as in any traditional product market, the fundamental behavior of consumers and firms determines market efficiency and net benefits from expanded choice.

Several recent papers have explored how salience and cognitive costs affect consumer decisions in a wide range of markets, including retail purchases, Medicare plans, credit cards, and public schooling (Chetty, Looney, and Kroft [2007], Kling et al. [2008], Ausubel [1991], Hastings and Weinstein [2008], respectively). ${ }^{1}$ Market outcomes may not be efficient if, for example, decision making costs cause consumers to place more weight on firm brand name relative to price than they would if prices were transparent and easy to understand. If decision making costs are negatively correlated with education, income, and wealth, then increased privatization and choice could increase disparities across socioeconomic groups in traditionally publicly provided markets (Hastings, Kane, and Staiger [2008], Hastings and Weinstein [2008]).

In the context of privatized social security, differences in financial literacy, investment experience, and education may significantly impact the choice of funds since decisions involve understanding financial concepts, such as compounding, inflation, risk, and return. ${ }^{2}$ If financially

\footnotetext{
${ }^{1}$ Borgans et al. (2008) summarize the related literature in psychology and outline approaches for incorporating personality and cognition in decision making and economic outcomes.

${ }^{2}$ Lusardi and Mitchell (2006) and Van Rooij, Lusardi, and Alessie (2007) show links between measures of financial literacy, savings behavior, and wealth at retirement using survey data from the US Health and Retirement Study and the Dutch National Bank household survey, respectively. Measures of financial literacy in both studies are compiled from respondents' ability to demonstrate basic understandings of financial concepts necessary to make investment decisions, such as the effects of compound interest, inflation, and risk on savings accumulation. In both surveys, many respondents fail to correctly answer basic questions on inflation, compounding, and risk. The researchers also
} 
illiterate participants face higher costs of interpreting information on fees, they may choose funds based on easier-to-determine characteristics, such as brand name. The resulting demand inelasticity may mitigate gains in retirement wealth from privatization for these consumers, and there may be market-level efficiency implications, as well. If large segments of investors are financially illiterate or face high decision making costs and choose funds based on brand name or convenience, rather than on low management costs, equilibrium fees may be significantly above competitive levels, negatively impacting wealth at retirement for all participants.

This paper uses data from a survey with an embedded experiment in Mexico's privatized social security system to examine how characteristics, such as income, education, investment experience, and financial literacy impact how workers view investment funds, called Afores (Administradoras de Fondos para el Retiro, pronounced Ah-FOR-ay), the extent to which workers minimize fees when selecting an Afore, and the degree to which information presentation can affect measures of price sensitivity among financially unsophisticated participants. ${ }^{3}$ The survey collected information on worker characteristics from 763 subjects, focusing on characteristics not available in administrative data. These included educational attainment, knowledge of the savings and retirement system rules, reasons for choosing the current Afore, sources of information used in selecting the Afore, savings behavior and experience, and measures of financial literacy. ${ }^{4}$ The survey was then followed by an information experiment, in which participants were presented with hypothetical Afore choices in different formats, to examine how typically unobserved consumer characteristics, such as financial literacy, impact stated price elasticity of demand and how receiving information in simplified

show an empirical link between financial literacy, savings, and planning for retirement, suggesting that differences in cognitive costs may contribute to differences in wealth at retirement. Moreover, researchers have found that even among relatively wealthy and educated investors, investors' decisions are overly responsive to defaults (Madrian and Shea [2001], Cronqvist and Thaler [2004]), information on past returns (Choi et al. [2007]), and the number of options offered for choice (Benartzi and Thaler [2001]).

${ }^{3}$ Mexico privatized social security in 1997, creating a fully funded system based on private accounts. Over the past decade, between eleven and twenty-one privately owned firms called Afores (Administradoras de Fondos para el Retiro) have provided fund management for the mandatory contributions of formal-sector labor market participants. Despite the relatively large number of firms to choose from, fees remain substantially higher than management fees for indexed mutual funds. High equilibrium fees may be due either to consumer behavior (demand inelasticity), firm behavior (anti-competitive behavior), or both. Hastings (2008) uses administrative data from social security accounts in Mexico and finds that this demand inelasticity is caused not only by decision making costs among workers, but also by regulations concerning how information on fees of firms are presented to workers .

${ }^{4}$ The surveys were collected in face-to-face interviews at malls and parks in Mexico City. Comparing our survey data to administrative data from the social security administration, we find that our sample is fairly representative of the population as a whole. 
format affected the price elasticity of demand, particularly among financially unsophisticated respondents.

The information experiments asked each subject to rank her top 3 choices for Afore when fees for the Afores in the market were presented in pesos per year instead of as an annual percentage rate on assets under management (the typical presentation format), when total fees over 10 years in pesos were presented instead of pesos per year, and when historic rates of return were given alongside information on fees. The relative prices of the Afores (and their returns, where applicable) varied randomly across surveys, providing a source of variation in addition to multiple ranked responses, to separately identify the importance respondents placed on price from unobservable characteristics of the Afore (such as brand-name quality).

We find that workers are fairly knowledgeable about the system. Approximately $81 \%$ of respondents were able to recall and write down the name of their Afore, and shares of Afores named by respondents closely match the actual shares of Afores in the market. While most respondents ranked fees as one of the most important factors determining their choice of Afore, we find that many workers lacked the financial literacy to answer basic questions about inflation and compound interest. Furthermore, few participants had experience investing in stocks, bonds, or mutual funds outside of their social security account.

Using the rank-ordered responses from the Afore choice forms, we find that respondents who scored high on financial literacy questions were much more price-sensitive when ranking Afores. This relationship remained even after allowing price sensitivity to vary with age, education, and salary. ${ }^{5} \mathrm{We}$ also find that financially illiterate workers pay much more attention to fees when fees are presented in pesos, but financially literate respondents have no change in choice behavior when given fees in pesos instead of in percentages. Since one of the determinants of financial literacy is correctly answering basic questions about compounding and inflation, these findings provide a link between measures of underlying financial skills and the ways in which agents are able to understand management fees.

Over all respondents, presenting fees in pesos instead of in percentages generated a 25 $55 \%$ increase in demand elasticity for Afore choices in our experiment. ${ }^{6}$ If all respondents were

\footnotetext{
${ }^{5}$ In addition, respondents who stated that fees were important to them when choosing their actual funds placed significantly higher weights on fees when selecting funds in our experiment.

${ }^{6}$ Specifically, we estimate the change in demand elasticity for each Afore, since each is modeled as a differentiated product. To translate changes in demand elasticity into changes in optimal fees, we assume that firms compete on
} 
financially literate, demand elasticity would increase by $74-134 \%$. Hence simply changing the format from percents to pesos has about a third of the impact on demand elasticity that financial literacy does, implying that providing information that makes fees more transparent and easy to understand may be a very cheap alternative to expensive education programs. We also examine the impact that presenting both information on fees and past returns has on price elasticity of demand and Afore choice. For financially illiterate, Afore brand name becomes a more important determinant of their choice when statistics on both fees and past returns are given to financially illiterate workers. ${ }^{7}$ This contributes to the overall decline in price elasticity of demand that each Afore hypothetically faces when consumers are given information on fees and past returns together.

These results have interesting implications for the presentation of government-mandated information and its potential to influence choices and competition in privatized social security markets. Because social security accounts cover financially literate and illiterate workers alike, presenting information in easy-to-understand calculations may have a significant impact on the ability of low-income and low-educated workers to understand fees and incorporate them into their decisions. Furthermore, presenting one statistic instead of multiple statistics may increase demand elasticity to that statistic (e.g., fees or returns-net-of fees) and minimize the weight workers place on brand name instead.

\section{Background on Mexican Privatized Social Security System}

\subsection{System Background and Regulations}

Mexico's privatized social security system has been in effect since July 1, 1997. The objective of the reform was to make the pension system financially viable, reduce the inequality of the previous pay-as-you-go system, and increase the coverage and amount of pensions, through the establishment of individual ownership over retirement account contributions. ${ }^{8}$ The

prices in a differentiated products market. The implied first-order conditions relate the profit-maximizing price-cost margin to the inverse of the firm's demand elasticity.

${ }^{7} \mathrm{We}$ will show that fees and returns are not significantly positively correlated in this highly-regulated investment market, so investors should not somehow infer that a high fee implies an abnormally high rate of return.

${ }^{8}$ Sinha (2003), PowerPoint presentation by CONSAR on "Modernization of the Mexican Pension System," New York, February, 2005. 
government approved private investment managers, previously introduced as Afores, to manage the individual accounts and established CONSAR (Comision Nacional del Sistema de Ahorro para el Retiro) to oversee this new Sistema de Ahorro para el Retiro (SAR). ${ }^{9}$ In June 2007, SAR had 37.5 million registered accounts. ${ }^{10}$ The economically active population in Mexico was 44.4 million and about $72.9 \%$ of the labor force participated in the formal sector. ${ }^{11}$ Total funds in the system exceeded 1.14 trillion pesos, which was approximately $12.5 \%$ of the expected 2007 GDP. ${ }^{12}$ Since its inception, there have been many changes in rules and regulations governing the system. We will describe the rules governing the system in place as of June of 2007 when the survey was conducted.

Mandatory contributions to the retirement account come from three places: the worker contributes a mandatory $1.125 \%$ of her base salary, the employer contributes an additional $5.15 \%$, and the government contributes $0.225 \%$ of the base salary, as well as a "social contribution" of $5.5 \%$ of the inflation-indexed Mexico City minimum wage (Sinha [2003]). ${ }^{13}$ The funds in the account are managed by the Afore that the worker chooses. Afores are approved by CONSAR, and each Afore is required to offer at least two specialized investment funds, called Siefores (Sociedades de Inversión Especializadas en Fondos para el Retiro, pronounced See-FOR-ay): A higher-risk fund called Siefore Básica 2 and a low-risk fund called Siefore Básica 1. The investment possibilities for each Siefore are heavily regulated by CONSAR. Siefore 1 is effectively restricted to investing in Mexican government bonds, and all workers over 55 years of age must have their funds in a Siefore 1. Siefore 2 may include investments in equities, but equity investments are capped at 15\%, and the investment vehicles are restricted to Principal Protected Notes and Exchange Traded Funds tied to major stock indices. Hence Siefores can be seen as fund managers that can invest in government bonds, high-rated corporate

\footnotetext{
${ }^{9}$ Initial reforms introduced in 1992 created private SAR accounts for workers at a bank of her choice, concurrent with participation in the partially funded scheme. However, all investment decisions were still made in a manner similar to the older system, but this role was largely limited to administrative tasks, such as record keeping and account statement generation (Sinha [2003]).

${ }^{10}$ Comisión Nacional del Sistema de Ahorra para el Retiro (CONSAR), Cuentas Administradas por las Afores, http://www.consar.gob.mx/boletin_estadistico/cuentas.shtml.

${ }^{11}$ Instituto Nacional de Estadística Geografia e Informática (INEGI), http://www.inegi.gob.mx.

${ }^{12}$ Comisión Nacional del Sistema de Ahorra para el Retiro (CONSAR), Fondos acum RCV, Vol y Vivienda, http://www.consar.gob.mx/estadisticas/2007/02/valor 0207.xls.

${ }^{13}$ In addition, another $5 \%$ of the worker's base salary is contributed to a housing account.
} 
bonds, and equity indices. Web Appendix B shows investment requirements and holdings for the Siefores. ${ }^{14}$

When a worker is first employed at a firm offering benefits, she must actively choose an Afore. Once registered with an Afore, the worker may transfer to another Afore fairly easily. ${ }^{15}$ There is no system-wide default option - workers must select an Afore. If an account starts but is not properly registered or attached to a worker (i.e., if the system does not know who owns the funds), the account is automatically assigned to an Afore according to rules established by CONSAR. These unassigned accounts typically have a very low balance and represent less that $5 \%$ of total assets under management.

Afores charged commissions on both flows (load fee) and on assets under management (balance fee). The fee is the same whether the account is invested in Siefore 1 or Siefore 2. The load fee is called a "flow fee" because it is quoted as a percent of the worker's salary instead of as a percent of the contribution to the account. Hence a flow fee of $1 \%$ is actually a $15.4 \%$ load fee $(1 / 6.5=0.154)$. In June 2007 , flow fees ranged from $0.5 \%$ - 1.6\% (i.e., a $7.7 \%$ - $25 \%$ load). In addition to the flow fee, firms charged balance fees ranging from $0.12 \%$ to $1.5 \%$. These two fees are published by CONSAR along with a combination of these two fees called the "1 Year Equivalent Fee on the Balance" or the "Equivalent Fee". ${ }^{16}$ The equivalent fee is the published fee that a firm would charge on balance alone to yield the same balance at the end of one year, based on its published flow and balance fee to a hypothetical worker with assumptions placed on monthly salary and balance. We will refer to this fee as the CEF (CONSAR's Equivalent Fee). The assumptions placed on the CEF significantly understated salary and overstated balance relative to workers in the system, skewing the equivalent fee downward, and substantially

${ }^{14}$ Comisión Nacional del Sistema de Ahorro para el Retiro (CONSAR), Cartera de Valores Básica 2, http://www.consar.gob.mx/estadisticas/2007/08/valor_0807.xls.

${ }^{15}$ Workers can switch Afores as often as they would like as long as the Afore to which they want to switch is less expensive than their current Afore. They can switch to any Afore once per year or whenever their current Afore raises its fees. As we will discuss later, most workers switch far fewer times than once per year, implying that this restriction is rarely binding. Workers can switch in several ways - over the phone by calling a toll-free number that CONSAR provides, over the internet at CONSAR's secure website, or by requesting the Afore to which they are switching to complete the request. All switches are centralized at an autonomous agency called PROCESAR (Empresa Operadora de la Base de Datos Nacional SAR), which is in charge of processing account data. This eliminates the ability of the Afores to make switching difficult or time consuming.

${ }^{16}$ In addition, most firms offer a small discount off their base fee that applies to workers who have been in the system for longer than a predetermined period. These discounts used to be applied based on the tenure of the worker with the Afore - effectively introducing a substantial switching cost over time. CONSAR required that, as of January 2005, all firms offer discounts based on the worker's tenure in the system instead of their tenure with the Afore. This substantially and exogenously changed the set of fees each worker faced when choosing whether to switch Afores. 
understating the fees actually paid by most workers in the system. Table 1 shows the June 2006 published CEF and distribution of actual equivalent fees paid by workers in each Afore; the actual fees paid are substantially higher than the published CEF representation of Afore's fees. ${ }^{17}$

To register for an Afore, workers were required to view the table of CEF's, along with each Afore's 3 year historic return, and sign a form stating that they had seen and understood the table of fees and returns as a part of the registration for an Afore account. If a worker were to switch online, she would have to acknowledge that she viewed the required fees and returns table, and every Afore is required to post this table on its website, as well, along with a statement that past returns do not guarantee future performance. We will return to this when we examine how viewing both fees and returns impacts demand elasticity of workers in our survey experiment. An example of this required table appears in Web Appendix C.

\subsection{Descriptive Statistics of Accounts and Fund Choices}

Table 2 shows summary statistics for a 10\% random sample of afiliados (registered account holders) in the system in June 2007. All financial statistics are reported in Mexican pesos unless otherwise noted. The symbol for a Mexican peso is $\$$, and 10.8 Mexican pesos $\approx 1$ US Dollar in June 2006. ${ }^{18}$ More than $60 \%$ of afiliados are men, reflecting the higher propensity of Mexican men to participate in the formal labor market. The wage distribution is skewed to the right - with a mean that is substantially larger than the median. The balance is also skewed to the right, and overall, pension account balances are relatively small (in comparison to US 401(k) accounts, for example). ${ }^{19}$ The average worker has been with her current Afore for 5.62 years and has been in the system for an average of 7.28 years. The mean number of switches (weighted by the number of years in the system) is about once every three years (0.3), although the median number of switches is once ever five years (0.21), and, in fact, the higher mean is driven mostly by an active upper tail that switches around once per year. Changes in Afore fees, changes in a workers' balances, wages, and labor market participation will change the optimal fund to invest

\footnotetext{
${ }^{17}$ Duarte and Hastings (2008) shows how this presentation impacts actual demand elasticity and Afore choices in the system.

${ }^{18}$ Banco de México, Tipos de Cambio, http://www.banxico.gob.mx/PortalesEspecializados/tiposCambio/indicadores.html.

${ }_{19}^{19}$ For example, the Employee Benefit Research Institute puts average 401(k) balance in the US at \$121,202 US Dollars (VanDerhei et al. [2007]).
} 
in, which suggests that workers may not be actively managing their accounts as much as they could.

Despite the seemingly large number of Afores to choose from and the range in fees across the Afores, ${ }^{20}$ few workers seemed to be choosing Afores to minimize fees. ${ }^{21}$ If we generate a rank of each Afore for each individual based on their actual fees paid, we find that the average person is in their $12^{\text {th }}$ ranked Afore out of $17 .^{22}$ The average person pays $6.12 \%$ of their balance in annual fees, and could cut that fee approximately in half by switching to their cheapest Afore. An average savings of 3.46\% of fees for assets under management represents a substantial amount of money left on the table. ${ }^{23}$ Column 4, of Table 2, shows the potential savings that afiliados could gain by switching from their current Afores to the cheapest Afores as a percentage of their balances. It is important to note that there is not a historical relationship between measures of persistent Afore performance and fees, implying that workers should not be choosing higher-fee funds because these higher fees cover higher costs of management for better performing firms. Web Appendix Table A.2 presents test for correlation between fees and historic performance. The lack of correlation may not be surprising given that the investment vehicles firms can use are highly regulated by CONSAR.

\footnotetext{
${ }^{20}$ In July 1997, seventeen Afores began operations (Sinha [2003]). Since then, there has been a consolidation wave followed by an entry wave. In early 2003, at its most consolidated point, the market consisted of 11 firms. Duarte and Hastings (2008) present graphs showing changes in fees from 2004-2006. Since then there have been several new entrants, so that as of June 2007, there were 21 Afores in the market. Web Appendix Table A.1 lists the Afores operating in the market in June 2007, with their entry date as well as a description of the firm. The Afores range from prominent Mexican banks like Banamex, and international investment firms like HSBC, to department store chains like Coppel (similar to Sears).

${ }^{21}$ Web Appendix Table A.2 presents results that test if fees are correlated with measures of market over- or underperformance and does not find evidence that they are. However the sample period is relatively small given the short history of the Afore market.

${ }^{22}$ To make this comparison, we calculate the fee that each firm would charge to each afiliado using her balance, her last recorded salary, and tenure in the system. We ranked the firms from cheapest to most expensive for each afiliado. Duarte and Hastings (2008) perform similar calculations using expected balances and wages going forward, and past average contribution rates and find basically the same fact - that workers are paying substantially more fees than they could if they switched to the cheapest fund. In addition, Duarte and Hastings (2008) show that this pattern remains even when examining choices of Afore at the time of choice. On average, workers choose only slightly less expensive funds, and over $25 \%$ of workers switch to Afores that are actually more expensive than the one they are currently in.

${ }^{23}$ Note that the $12^{\text {th }}$ cheapest means that there are approximately 12 Afores that they could have chosen that would have charged them a cheaper management fee. Also, each afiliado pays an average CEF of $2.86 \%$ and the average $\mathrm{CEF}$ that would be charged by the cheapest Afore for each afiliado is $1.52 \%$. The average CEF rank of each afiliado's current Afore is 11.45 out of 17 .
} 


\section{Survey and Field Experiment}

\subsection{Description of the Survey and Field Experiment}

To examine how demographics such as education, financial literacy, savings and investment experience influence Afore choice and price elasticity of demand, we conducted a survey and field experiment in Mexico City in June 2007. The survey was administered in parks and malls around Mexico City - covering areas where people from all economic backgrounds spend time with their families on weekends. We hired a team of 12 surveyors from local government agencies, universities, and NGOs in Mexico City to help administer the survey. Potential respondents were approached by a surveyor who stated that they were with a group from Yale University, conducting a study of the savings and retirement system, and they were informed that their responses would be anonymous and confidential. We collected 763 surveys in total. Most respondents spent approximately 30 minutes completing the survey.

The first portion of the survey consisted of three pages of questions that gathered information on demographics, choice and savings behavior, and measures of financial literacy. An example of the questions appears in Web Appendix D. Where appropriate, response options were randomly varied across surveys. Questions 1-12 collected basic demographic information as well as information unavailable in administrative data, including education, marital status, number of children, internet access, and internet usage. We also collected information on employment status in the formal sector, employment title, and income. Questions 13-24 asked respondents questions about their current Afore choice and their knowledge of and participation in the SAR.

The final 3 questions of the survey were designed to construct a measure of financial literacy, modeled after the US Health and Retirement Study (HRS) Module 8 on Retirement Planning (HRS [2004]). The first question measures whether an individual understands compound interest by asking if she would have more, less, or equal to 1500 pesos at the end of five years if she invested 1000 pesos today at $10 \%$ annual return. The second question gauges whether a person understands inflation by asking if she would be able to buy more or less with her money at the end of a 1 year investment if inflation were $2 \%$ and investment returns were $1 \%$, The third question tests familiarity with financial investments, such as mutual funds and 
stocks, by asking participants to select from possible relationships between past and future returns. One of the options is to select the familiar phrase that "past returns do not predict future performance" highlighted on Afore websites and printed materials. In all cases, the option "I don't know" and the option "Prefer not to answer" were both listed to minimize the chance of guessing (Lusardi and Mitchell [2006]).

These three pages were followed by four separate hypothetical sets of information on Afores. The respondents were told that they needed to advise their brother on which Afore to choose for his SAR account. They were to consider the subsequent hypothetical information on the Afores given by CONSAR to assist with Afore choice and rank their top 3 Afore choices. The table was similar to CONSAR's actual table of information and real names of Afores were used, but the relative fees varied randomly across surveys so that we could estimate price sensitivity in a choice model incorporating the realistic value of Afore brand name. Each sheet presented information designed to test how simplified information and framing of information would impact Afore choice and price sensitivity. There were six types of information framing each participant received 4 of these types. Examples of these sheets are given in Web Appendix E. The six basic information frames were: 1) Fees presented as a percentage of balance (how fees are typically presented), 2) Fees presented as pesos charged per year (simplifying the fees by performing multiplication for the worker), 3) Fees presented as 10 year total fees paid in pesos (changing the framing of the fees to increase the size), 4) Account balances after 10 years (framing the Afore choice as account balance gains instead of costs), 5) Fees presented with 1 year past returns, or 6) Fees presented with 1 and 3 year past returns.

Each survey contained a randomly selected combination of 4 of these sheets. ${ }^{24}$ The fees and returns were drawn from the actual distribution of fees and returns for the Afores, so they were realistic. However, the relative fees (and returns, if applicable) for each Afore listed on each sheet were randomized across surveys and across sheets within a survey, allowing us to measure demand elasticities based on the stated choices of each respondent in each table. In addition, fees in all formats were calculated using the appropriate equivalent fee formula, and underlying fees were expressed as a percentage of balance. This allowed us to convert all fees

\footnotetext{
${ }^{24}$ Only 4 sheets were used in each survey because initial tests suggested that more than 4 sheets was too long. There were 3 different combinations of these 4 sheets, and each respondent was randomly given a survey with one of these combinations. The fees of the firms varied both within and across the 3 different overall formats.
} 
(whether pesos per year or pesos per 10 years) back into a percentage of balance to make the appropriate regression comparisons of the effect of information framing on demand elasticity.

\subsection{Analysis of Survey Responses}

Table 3 compares demographic characteristics of our survey sample with those of the population in the administrative data. The population in this case is a snapshot from the administrative database for June of 2007 for all afiliados residing in Estado de Mexico and Distrito Federal (Mexico City). Column 1 gives summary statistics for our sample, while Columns 2-4 give the population mean when available with confidence intervals for the population mean given the sample variance and our sample size. Our sample has a higher average salary driven by a slight under-sampling of the lowest-income workers and oversampling of the highest-income workers; however, we have density in all areas of wage distribution. For demographic variables in the survey but not in the administrative data, the majority of survey participants have a high school degree or higher and over two thirds of respondents had access to the internet, either at home or at the office.

Overall, respondents were fairly knowledgeable about their accounts and about the savings and retirement system. Approximately $81 \%$ of respondents knew and could write down on the survey the name of their current Afore, and the market shares of the respondents' stated Afores were fairly representative of the actual Afore market shares in the population in June 2007. In addition, $79 \%$ of respondents considered their SAR account as part of their personal wealth, and $86 \%$ knew that they could switch Afores for free.

Table 4 presents results from probit regressions of whether a respondent ranked a particular reason as one of the top three reasons she chose her current Afore on responses to demographic questions. The first row gives the mean of the dependent variable; the fraction of people who listed that reason as one of the top three reasons why they chose their Afore. The first column shows that respondents with a post-high school education and respondents who use the internet often for paying bills, making reservations, or reading the news are more likely to list financial stability as a top reason for choosing their Afore. In addition, Internet users and/or those with Internet access (survey questions 7 and 8) value an Afore more if they have other accounts with that bank, and they are less likely to value easy branch access or "good service" 
when choosing an Afore (perhaps for online banking and account management). Interestingly, receiving payroll through an Afore is most important for low-income workers, as is easy branch access. Most importantly, higher-educated workers are more likely to state that low fees are an important determinant of choice, but they are also more likely to look for higher past returns.

Table 5 presents results from probit regressions of whether a respondent ranked a particular information source as her primary information source for choosing her Afore (survey question 17) on respondent's demographics. The first row gives dependent variable means and shows that, while CONSAR is a major source of information $(21.6 \%)$, people are most likely to get their information from the Afores through Agentes Promotores (Afore sales agents; mean response of $26.9 \%$ ). Women and low-income workers are more likely to rely on their employer for information when choosing an Afore, while men and internet users are much more likely to rely on information published by CONSAR. There is no significant difference across demographic groups in the extent to which information from Afore agents is used in deciding on which Afore to go with. The survey results on stated reasons for choices and sources of information suggest that low-income and lower-educated individuals may be less sensitive to fees, relying more on their employer's advice or the Afore that is affiliated with the bank that provides payroll at their employer. In addition, they seem to value product differentiation through service and branch access - both characteristics that may given them added value from large banks such as Banamex and at the same time make them less likely to respond to lower prices by choosing another Afore.

One reason that low-income and/or lower-educated workers may rely more on their employers and local branch services when choosing an Afore, focusing less on fees and returns, may be because they have little experience with financial savings and investment in general. Survey question 24 asked respondents to list which type of vehicles they use for savings (outside of their SAR account), and very few respondents indicated that they had experience with financial instruments, such as stocks or bonds. For a large fraction of people, their Afore is the only experience they have with investing money outside of informal savings networks. Table 6 shows that only $16 \%$ of people report that they save through equities, debt, or foreign securities. Almost half of the respondents do not even save in a bank, saving instead in informal networks 
of friends, families, or employee cooperatives. ${ }^{25}$ As expected, education and income are much lower for respondents who do not save or who save in informal networks or cooperatives. Of workers who do not save, only $32.2 \%$ have greater than a high school education, while almost $90 \%$ of respondents who save in stocks or bonds have post-high school education. Average salary triples from those who say they do not save to those who save in sophisticated financial assets $(\$ 5,809$ versus $\$ 18,967)$.

These statistics imply that many people may not be familiar with basic calculations needed to make wise investment decisions when planning their retirement savings and choosing between the Afores in the market. To examine financial literacy, we asked 3 questions (survey questions 25-27) motivated by the financial literacy module in the HRS. We asked a question that measured respondents' understanding of compounding, one that measured their understanding of inflation, and one that tested their knowledge of the relationship between past and future returns emphasized by investment firms. ${ }^{26}$ Using the answers we formed a financial literacy index that is the sum of correct answers across the three questions (Lusardi and Mitchell [2006], Van Rooij, Lusardi, and Alessie [2007]). ${ }^{27}$ Overall, 32\% of respondents answered the compounding question correctly, $65 \%$ of respondents answered the inflation question correctly, and 23\% demonstrated knowledge of investment returns terminology by selecting "past returns do not predict future returns" in question 27. When we sum the number of correct answers, we find that $26 \%, 39 \%, 25 \%$ and $10 \%$ of respondents answered $0,1,2$, and 3 questions correctly, respectively. Our measure of financial literacy is positively correlated with education, salary, and savings sophistication, as expected. Table 7 shows averages for these variables by the number

${ }^{25}$ Tandas are informal savings networks typically between families and relatives. Cooperativas are savings cooperatives typically formed by co-workers. The employer often acts as the "bank" overseeing the worker savings cooperative and providing interest on the deposits. Cajas de Ahorro or Solidarias are small local cooperative savings communities that formed after pesos crises in the early 1990s when people lost trust in formal financial institutions.

${ }^{26}$ As in the United States, all investment firms in Mexico, including the Afores, must clearly state that "past returns do not predict future performance" when providing statistics on past returns.

${ }^{27}$ Knowing ahead of time that investments in mutual funds, stocks and bonds are much more prevalent in the United States than in Mexico, we replaced the question in HRS Module 8 on risk in a mutual fund versus in a stock with the question on past returns. In both questions, it is not clear what the correct answer is, since it is possible for a stock to be riskier than some narrow mutual funds and there is some evidence of persistent performance across actively managed funds. However, both questions measure the degree to which respondents are familiar with commonly expressed financial concepts. The past returns question also allow us to measure a stated response that could help predict changes in Afore choices in the information framing test that examined how Afore choices changed when respondents were given information on fees alone, fees with 1 year returns, or fees with 1 year and 3 year past returns. 
correct responses to the financial literacy questions. Average salary increases significantly with the index, but there is still significant variation in salary within each cell.

\subsection{Analysis of Hypothetical Afore Choices}

To test if information might affect Afore choice and price elasticity of demand, we analyzed the stated choices of each respondent on the Afore choice sheets they received as the final part of their survey. Recall that each respondent was asked to rank her top three choices for an Afore based on the hypothetical information from CONSAR provided to her on each sheet. We use these rankings to measure the implicit weight each respondent attached to fees when choosing an Afore and how that weight varies with financial literacy and the type of information presented. The parameter estimates can then be used to calculate demand elasticities for each Afore implied by the choices made in each information format.

\subsubsection{The effect of viewing fees in pesos versus in percentages}

We begin by examining the reduced-form effect that viewing a table of Afore fees in pesos instead of in percentages has on the fee of the first-choice Afore. There are two experiments: viewing annual fees in pesos versus in percentages and viewing fees in pesos over ten years versus the annual fees in pesos. Table 8 shows the reduced form impact that each of these treatments has on the fee of the first-choice Afore. Column 1 does not include covariate controls, while column 2 does. The treatment effect estimates are very similar across the two columns. Both indicate that seeing fees in pesos per year or pesos over ten years leads to a 6-7 basis point reduction in the fee of the first-choice Afore relative to viewing fees in annual percentage rates. In addition, if we look at the covariates in column 2, this effect is a little more than one third of the effect that being financially literate has on the fee of the first-ranked Afore, and about one half of the effect that being a person who stated they look for fees when selecting their actual Afore has. However, these covariates together explain very little of the overall variation in Afore choice. The reduced-form approach excludes the importance of other factors when ranking the Afores, such as brand name. It also does not allow us to quantify what these changes in fees paid might mean from the firm's perspective as a hypothetical impact on overall demand elasticity. 
We can estimate the implicit importance attached to fees relative to other factors when ranking the Afores utilizing all three ranked choices, by estimating a rank-ordered conditional (individual fixed-effects) logit model of Afore choice, where the indirect utility function for person $i$ choosing Afore $j$ is given by:

$$
U_{i j}=X_{i j} \delta+\alpha p_{j}+\theta T_{i} p_{j}+p_{j} Z_{i} \gamma+\varepsilon_{i j}
$$

where $X_{i j}$ is a matrix of Afore dummies and an indicator for whether Afore $j$ is the Afore that person $i$ currently holds their account with, $p_{j}$ is the price of Afore $j$ in annual percent charged on balances, $T_{i}$ is an indicator for whether person $i$ viewed fees in pesos rather than in percentages, $Z_{i}$ is a matrix of characteristics for $i$ such as income and financial literacy, and $\varepsilon_{i j}$ is an i.i.d. extreme value error term. ${ }^{28}$ Because we randomized the fees across tables and solicited each respondent's top three choices, we are able to include Afore fixed effects, as well as an indicator for the respondent's current Afore, in each regression to control for unobserved brand value. We can then use the estimates to calculate the effect that information has on the importance placed on fees and the overall demand elasticity that each Afore hypothetically faces.

Table 9 presents results across four specifications. Column 1 presents results pooling the Afore choices across respondents who were given information on fees in annual percentage rates or in pesos in either format. It also excludes financial literacy as a factor that determines price elasticity. Column 2 includes financial literacy in the pooled specification. Columns 3 and 4 allow for price elasticity to vary with whether the respondent was given fees as a percentage or fees as pesos per year (in either format). Note, to save on space, we report coefficients on only the Afores whose fixed effects were significantly different from zero (relative to the excluded Afore, Profuturo GNP).

Comparing the results in Columns 1 and 2, we see that financial literacy is a key determinant of the weight workers place on price, dominating the effect of income, and larger in magnitude than an indicator for whether the person stated they valued fees when selecting an Afore in the survey portion of the experiment. Getting 2 or more correct answers in the financial

\footnotetext{
${ }^{28}$ We don't estimate a mixed logit because we allow for many interactions between individual characteristics and price. Many of these characteristics, such as financial literacy and stated preference for fees when selecting a fund, can be interacted directly with price using our survey data, even though they would be unobserved in administrative data and enter instead through idiosyncratic preferences for fees in a mixed logit model.
} 
literacy section (financial literacy score $>=2$ ) nearly doubles the implicit weight respondents placed on fees when choosing an Afore.

Column 3 shows that the implicit weight respondents place on fees increases by about $50 \%$ (coefficient of -0.319 off a base of -0.750 ) when respondents see fees expressed in pesos rather than in an annual percentage rate. The effect is half as large as the effect of being financially literate $(-0.791)$, or stating that fees are the most important factor in Afore choice $(-0.596)$. Column 4 further breaks down the effects of viewing fees in pesos versus percentages by financially literate and illiterate respondents. If financial literacy enables people to understand, process, and incorporate information on annual percentage rates when choosing Afores, we might expect a higher impact of informational format on the financially illiterate respondents. This is exactly what we find. All of the impact of viewing fees in pesos on price sensitivity accrues to financially illiterate respondents. Viewing fees in pesos almost doubles the weight they place on fees (intercept of -0.593 and treatment effect of -0.521). However, viewing fees in pesos has no effect on the price sensitivity of financially literate respondents (total treatment effect of $-0.521+0.754$ is not statistically different from zero).

\subsubsection{The effect of viewing both past returns and fees}

We can also use the Afore choices to compare how the weight placed on fees changes when viewing information on both fees and past returns. Following Choi et al. (2007), we allowed for positive correlation between fees and past returns, so that chasing past returns would raise the fee paid with certainty and therefore lower expected future returns, even though returns (relative to the market average) are not significantly correlated with fees. This relationship was true in the sheet providing information on 1 year past returns, as well as the sheet that provided 1 year and 3 year past returns. In addition, in the sheet providing 1 year past returns, we allowed 1 year and 3 year returns to be slightly negatively correlated to examine if viewing information that past returns are variable within Afore would cause respondents to place a higher weight on fees and less weight past returns.

Table 10 shows the reduced form impact of the different information formats on the fee of the first-choice Afore. The first column shows just differences in means without controlling for demographic characteristics. The first coefficient after the constant shows just the effect of seeing fees in pesos versus percentages, given that only fees are shown. The second coefficient 
gives the added effect of seeing pesos instead of percentages when both fees and past returns are given. The impact of seeing pesos on the fee of the first-choice Afore is positive and doubles in magnitude when both fees and returns are shown in pesos, suggesting that viewing fees and returns in pesos helps respondents process both types of information, and to the extent that they focus on past returns, viewing pesos increases the fee of the first-choice firm more than viewing information in percentages. In addition, viewing information on one year past returns increases the price of the first-choice Afore by 0.291 percentage points. Seeing information on both 1 year and 3 year past returns increases the fee of the chosen afore by significantly less, 0.212 , suggesting that agents are less prone to return chasing when they view two sets of past returns that demonstrate variability in past returns. The second column presents the same coefficient estimates controlling for demographics. As in Table 12, financially literate respondents and those who stated they considered fees as an important determinant of their Afore choice, chose Afores that have lower average fees in the experimental tables.

Table 11 estimates a rank-ordered logit model of Afore choice using responses from forms showing 1 year, as well as 1 and 3 year past returns. Columns 1 shows that on average, respondents place a higher weight on fees than they do on past returns, but on average, they place positive weights on past returns, and in addition, the magnitude of the coefficient on price relative to the value placed on own Afore indicates that respondents place less absolute weight on fees when both fees and past returns are presented. In Table 9, the average respondent valued a 1 percentage point decrease in fees as much as they valued their current Afore. In Table 11, respondents value a 1 percentage point decrease in fees only $1 / 3$ as much as they value their own Afore. Thus, not only do respondents place a positive and significant weight on past returns when both fees and past returns are presented, but they place substantially less importance on fee information, all else equal. Column 2 presents results for formats presenting both 1 year and 3 year past returns. Here respondents correctly place higher importance on past returns over 3 years rather than 1 year, but they still place a significant weight on 1 year past returns. In addition, viewing both types of past returns again decreases the importance of fees relative to other factors, such as own Afore, when comparing the ratios of coefficients to those in column 1 and in Table 9.

Columns 3 and 4 allow the value placed on fees and returns to vary by financially literate and illiterate respondents. As in Table 9, financially literate respondents place significantly more 
weight on fees than illiterate respondents do. However, financially literate respondents also place higher weights on past returns as well. Both illiterate and literate respondents place lower weights on 1 year past returns when 3 year returns are shown as well. However, when both 1 and 3 year returns are shown, financially illiterate workers do not place a significant negative weight on fees, instead only 3 year past returns are significant determinants of their choices. Hence, financially illiterate workers appear to choose their Afore almost completely on brand name when information on fees and past returns are presented.

\subsubsection{Impact on demand elasticity facing each Afore}

Using estimates from Tables 10 and 11, we can calculate the demand elasticity that each Afore would hypothetically face under different conditions. For each column, we analytically compute the demand elasticities each Afore faces evaluated at the parameter estimates from the corresponding rank-ordered conditional logit model. ${ }^{29}$ Column 1 of Table 12 gives demand elasticity estimates for each Afore implied by the demand estimates in Table 9 column 4, assuming that everyone received information only on fees expressed as an annual percentage rate. Overall demand is elastic, with demand elasticities ranging from -1.45 to -1.86 . Column 2 computes the demand elasticity that each Afore would face if all consumers received fees in pesos instead of in annual percentage rate terms. Demand elasticity increases by $25-55 \%$ from column 1 to column 2, indicating a substantial impact of the simple change in format on stated demand elasticities. Column 3 calculates demand elasticities assuming that all people are financially literate. This is an interesting statistic for comparing the potential impact of a simple change in information format versus the impact of moving a consumer population towards financial literacy. Column 3 shows that if all people were financially literate, hypothetical demand elasticity would increase by $74-134 \%$ across Afores. Comparing the impact on demand elasticity moving from column 1 to column 2 versus column 3 implies that a simple change in information format has about $34-44 \%$ of the impact on demand elasticity that increasing financial literacy might have. ${ }^{30}$

\footnotetext{
${ }^{29}$ Note that this is not the actual demand elasticity a firm might face in the market, but instead is useful for quantifying and comparing changes in price sensitivity across different conditional logit models with different scale factors. For an outline of factors that affect demand and the firm's optimization problem in the Afore market, please see Duarte and Hastings (2008).

${ }^{30}$ In addition, note that the largest brand-name banks (Banamex, Bancomer, Banorte, Santander) also have some of the largest estimated changes in demand elasticity from providing simplified information or increasing the financial
} 
Columns 4 and 5 compute demand elasticity from responses where both fees and past returns are presented (in either pesos or annual percentage rates) for 1 year past returns, as well as 1 and 3 year past returns, respectively. Overall demand elasticity decreases substantially when compared to column 1. The computed elasticities in both of columns imply that presenting information on fees and returns substantially reduces price elasticity of demand. The demand elasticities in columns 4 and 5 are similar in magnitude to those found using actual administrative data, and the information presented in these two formats are the most similar to the required information from CONSAR (Duarte and Hastings [2008]). In addition, Column 6 presents the price elasticity of demand to the CEF using the survey respondent's stated Afore and the choice set they faced during the time period they chose that Afore (constructed using the midpoint of the number of years the individual stated that they had been with that Afore). The demand elasticities are similar to those in Columns 4 and 5, although they are slightly sensitive to the assumption on exactly when the individual chose their Afore.

Another way to interpret the impact of these hypothetical choices on demand elasticity and overall fees in the market is to compute the change in optimal price-cost margin for each firm assuming firms compete on prices in a static, differentiated products market. ${ }^{31}$ From Table 12, for example, viewing fees in pesos instead of percents decreased the fee of the first-choice Afore by 0.07 off a base of 1.70 , implying a relative small decrease in fees paid of $4 \%$. However, in a market setting where prices are high, inducing consumers to pay greater attention to price may result in a small immediate savings for them, but a much larger savings through the effect increased demand elasticity has on optimal firm prices. In column 1 of Table 13, the implied Afore price-cost margins range from $54-69 \%$. The increased demand elasticities in column 2 translate into a $20-35 \%$ reduction in price-cost margins, and those in column 3 imply a $42-$ $57 \%$ decrease in price-cost margins across Afores. Hence, a hypothetical market-wide increase in

\footnotetext{
literacy levels. These banks also serve predominantly financially illiterate and lower-income customers. In our survey response, respondents who stated they were currently an affiliate of one of these Afores were more likely to be financially illiterate (68-70\% financially illiterate). In addition, in the administrative data, these firms have afiliados with lower than average salary and balance given their age. These relatively high fee firms have a strong brand name, and serve financially illiterate workers, and hence face the largest hypothetical change in demand elasticity (and therefore decrease in optimal fees) as a result of increased financial literacy or simplified information that increases the price sensitivity of financially illiterate customers.

${ }^{31}$ In this setting, the firm's optimal price-cost margin is proportional to the inverse of their demand elasticity. Since the firms offer differentiated products, demand elasticity varies for each firm.
} 
price sensitivity can substantially lower Afores' optimal prices, even if it has only a marginal impact on the immediate price paid when viewed in isolation of potential market effects.

\section{Conclusion}

This paper examines the links between investor characteristics such as financial literacy, information format, and measures of investment choice behavior, using data collected from a survey and field experiment in Mexico's privatized social security system. We find that, while many participants in the system are well informed about their choices, few have experience investing in financial assets such as stocks, bonds, or mutual funds outside of their mandatory savings and retirement account. In addition, we show that financial literate respondents place much higher importance on fees relative to brand name when selecting funds in a hypothetical situation. This implies that wealth accumulation in a privatized system will be on average higher for these individuals. However, we also find that simple changes in format presentation, presenting fees in pesos charged rather than as an annual percentage rate, can have a significant effect on the weight financially illiterate respondents place on fees, implying that the ability to understand basic financial concepts such as compounding has a significant impact on how individuals interpret and choose funds when faced with comparative fee tables.

In addition, we show that all respondents place lower weights on fees when past returns are included in the information presentation. This is particularly pronounced for financially illiterate workers, who place near zero weight on fees or returns, focusing much more on firm brand name when simultaneously presented with multiple pieces of information on fees and returns. While information presentation has a modest impact on the fee of the first-choice Afore, holding fees constant, by translating the impact of information into a demand elasticity, we find that changes in information have very large implied impacts on demand elasticities and on calculations for price-cost margins in the market. The increase in price sensitivity that induces workers to list first-choice Afores with $0.07 \%$ lower annual fees, holding fees constant, is equivalent to a $25-55 \%$ increase in demand elasticity. This implies that, although the reducedform impact on an individual's choice may not lead to substantial increase in wealth accumulation, the increased competitive pressure on firms may lower fees by $20-35 \%$ percent, potentially resulting in a substantial market improvement in efficiency and wealth accumulation. 


\section{References:}

Ausubel, Lawrence M. (1991). "The Failure of Competition in the Credit Card Market." American Economic Review, 81(1): 50-81.

Benartzi, Shlomo, and Richard H. Thaler. (2001). "Naïve Diversification Strategies in Defined Contribution Saving Plans." American Economic Review, 91(1): 79-98.

Borgans, Lex, Angela L. Duckworth, James J. Heckman and Bas ter Weel (2008). "The Economics and Psychology of Personality Traits." Journal of Human Resources, 43(4): 972-1059.

Chetty, Raj, Adam Looney, and Kory Kroft. (2007). "Salience and Taxation: Theory and Evidence." NBER Working Paper No. 13330.

Choi, James J., David Laibson, Brigitte C. Madrian, and Andrew Metrick. (2007). "Reinforcement Learning and Investor Behavior." Working Paper, Yale University.

Cronqvist, Henrik, and Richard H. Thaler. (2004). "Design Choices in Privatized Social-Security Systems: Learning from the Swedish Experience." American Economic Review (Papers and Proceedings), 94(2): 424-428.

Duarte, Fabian, and Justine Hastings. (2008). "Consumer Behavior in a Private Social Security System: Implications for Competition and Distribution of Wealth at Retirement." Unpublished Manuscript, Department of Economics, Yale University.

Feldstein, Martin, and Andrew Samwick. (1999). "Maintaining Social Security Benefits and Tax Rates through Personal Retirement Accounts: An Update Based on the 1998 Social Security Trustees Report." NBER Working Paper No. 6540.

Feldstein, Martin, and Jeffrey B. Liebman. (2001). "Social Security." NBER Working Paper No. 8451 .

Geanakoplos, John, Olivia S. Mitchell, and Stephen P. Zeldes. (1998). “Social Security Money’s Worth.” NBER Working Paper No. 6722.

Hastings, Justine S. (2008). "Worker Behavior, Firm Behavior, and Equilibrium Fees in Mexico's Privatized Social Security Market." Unpublished Manuscript, Department of Economics, Yale University.

Hastings, Justine S., Thomas J. Kane, and Douglas O. Staiger. (2008). "Heterogeneous Preferences and the Efficacy of Public School Choice." Formerly NBER Working Papers No. 11805 and No. 12145. Available at http://aida.econ.yale.edu/ jh529/HKS Combined_200806.pdf. 
Hastings, Justine S., and Jeffrey M. Weinstein. (2008). "Simplified Information, School Choice, and Academic Achievement: Evidence from Two Experiments." Quarterly Journal of Economics, 123(4): forthcoming November 2008.

Kling, Jeffrey R., Sendhil Mullainathan, Eldar Shafir, Lee Vermeulen, and Marian V. Wrobel. (2008). "Misperceived Prices: Medicare Drug Plan Choice." Unpublished Manuscript, Harvard University.

Lusardi, Annamaria, and Olivia S. Mitchell. (2006). "Financial Literacy and Planning: Implications for Retirement Wellbeing." Wharton School Pension Research Council Working Paper 2006-1.

Lusardi, Annamaria, and Olivia S. Mitchell. (2007). "Baby Boomer Retirement Security: The Roles of Planning, Financial Literacy, and Housing Wealth." Journal of Monetary Economics, 54(1): 205-224.

Madrian, Brigitte C., and Dennis F. Shea. (2001). "The Power of Suggestion: Inertia in 401(k) Participation and Savings Behavior.” Quarterly Journal of Economics, 116(4): 11491187.

Sinha, Tapen. (2003). Retrospective and Prospective Analysis of the Privatized Mandatory Pension System in Mexico (Monograph M-RS02-1). Schaumburg, IL: Society of Actuaries.

The Health and Retirement Study (HRS). (2004). "Documentation.” Retrieved May 18, 2007 from http://hrsonline.isr.umich.edu.

VanDerhei, Jack, Sarah Holden, Craig Copeland, and Luis Alonso. (2007). “401(k) Plan Asset Allocation, Account Balances, and Loan Activity in 2006." Employee Benefit Research Institute Issue Brief No. 308. Available at http://www.ebri.org/pdf/briefspdf/EBRI_IB_08-20073.pdf.

Van Rooij, Maarten, Annamaria Lusardi, and Rob Alessie. (2007). "Financial Literacy and Stock Market Participation." De Nederlandsche Bank Working Paper No. 146. 
Table 1: CEF vs. Actual Equivalent Fees for June 2006

\begin{tabular}{|lccccc|}
\hline \multicolumn{1}{rc}{ Afore Name } & \multicolumn{3}{c}{$\begin{array}{c}\text { Fee as \% of Balance } \\
\text { (all accounts) }\end{array}$} & \multicolumn{2}{c|}{$\begin{array}{c}\text { Fee as \% of Balance } \\
\text { (accounts in that Afore) }\end{array}$} \\
\hline \hline Actinver & CEF & Average & Std. Dev. & Average & Std. Dev. \\
Afirme Bajío* & $2.02 \%$ & $4.02 \%$ & 4.10 & $4.01 \%$ & 3.88 \\
Azteca & $1.52 \%$ & $2.98 \%$ & 2.85 & $15.89 \%$ & 2.31 \\
Banamex & $2.22 \%$ & $4.53 \%$ & 4.62 & $3.95 \%$ & 3.73 \\
Bancomer & $3.16 \%$ & $6.28 \%$ & 6.23 & $6.35 \%$ & 6.14 \\
Banorte Generali & $3.02 \%$ & $5.93 \%$ & 5.64 & $5.00 \%$ & 5.29 \\
Coppel** & $2.99 \%$ & $6.01 \%$ & 5.83 & $7.14 \%$ & 6.23 \\
HSBC & $2.21 \%$ & $4.37 \%$ & 4.22 & - & - \\
Inbursa & $3.11 \%$ & $6.23 \%$ & 6.12 & $5.72 \%$ & 5.68 \\
ING & $1.53 \%$ & $2.71 \%$ & 2.29 & $1.93 \%$ & 1.79 \\
Invercap & $3.01 \%$ & $6.14 \%$ & 6.06 & $5.66 \%$ & 5.51 \\
IXE & $2.17 \%$ & $4.35 \%$ & 4.38 & $4.05 \%$ & 3.71 \\
Metlife & $2.40 \%$ & $4.71 \%$ & 4.62 & $4.20 \%$ & 3.62 \\
Principal & $2.67 \%$ & $5.35 \%$ & 5.35 & $4.49 \%$ & 4.07 \\
Profuturo GNP & $3.48 \%$ & $6.93 \%$ & 6.92 & $9.17 \%$ & 7.71 \\
Santander & $3.00 \%$ & $6.44 \%$ & 6.54 & $6.45 \%$ & 6.23 \\
XXI & $3.15 \%$ & $6.15 \%$ & 5.87 & $5.72 \%$ & 5.59 \\
\hline NXI & $2.89 \%$ & $5.83 \%$ & 5.86 & $7.99 \%$ & 7.72 \\
\hline
\end{tabular}

Notes: CEF comes from published tables by CONSAR for the 1 Year Equivalent Fee on the Balance, available at http://www.consar.gob.mx/boletin_estadistico/comisiones.shtml. Columns 2 and 4 give actual average fee paid expressed as a percent of the balance for all accounts in the system and for all accounts in each Afore, respectively. Calculations were done using account-level data from June 2006. *Afirme Bajió had just opened with very few accounts, and most of these accounts were people who paid relatively high commissions given its flow and balance fees (high wage relative to balance). **Afore Coppel just opened and had an insignificant market share. 
Table 2: Summary Statistics for Afiliados, December 2006

\begin{tabular}{|c|c|c|c|c|c|c|}
\hline & Mean & $\begin{array}{c}5^{\text {th }} \\
\text { Percentile } \\
\end{array}$ & $\begin{array}{c}25 \text { th } \\
\text { Percentile } \\
\end{array}$ & Median & $\begin{array}{c}75^{\text {th }} \\
\text { Percentile } \\
\end{array}$ & $\begin{array}{c}95 \text { th } \\
\text { Percentile }\end{array}$ \\
\hline \multicolumn{7}{|l|}{ Demographics } \\
\hline Male & 0.62 & -- & -- & -- & -- & -- \\
\hline Age & 36.29 & 21.49 & 27.24 & 33.86 & 43.24 & 59.52 \\
\hline Monthly Salary* & $\$ 5,483$ & $\$ 1,506$ & $\$ 2,147$ & $\$ 3,314$ & $\$ 5,798$ & $\$ 18,014$ \\
\hline Account Balance & $\$ 18,024$ & $\$ 0.00$ & $\$ 2,011$ & $\$ 8,473$ & $\$ 21,655$ & $\$ 69,144$ \\
\hline \multicolumn{7}{|c|}{ System Affiliation and Afore Choice } \\
\hline Tenure in Current Afore & 5.62 & 0.25 & 1.71 & 6.37 & 9.26 & 9.67 \\
\hline Tenure in System & 7.28 & 2.01 & 5.51 & 8.38 & 9.42 & 9.72 \\
\hline Number of Switches per & & & & & & \\
\hline Years in System & 0.32 & 0.00 & 0.11 & 0.21 & 0.36 & 0.85 \\
\hline Rank of Current Afore & 12.5 & 4 & 11 & 13 & 15 & 17 \\
\hline Fee Current Afore & $6.12 \%$ & $0.96 \%$ & $2.17 \%$ & $3.69 \%$ & $7.78 \%$ & $19.74 \%$ \\
\hline Fee at Cheapest Afore & $2.66 \%$ & $0.57 \%$ & $1.15 \%$ & $1.81 \%$ & $3.32 \%$ & $7.77 \%$ \\
\hline Potential Fee Savings & $3.46 \%$ & $0.17 \%$ & $1.04 \%$ & $1.89 \%$ & $4.46 \%$ & $12.03 \%$ \\
\hline
\end{tabular}

Notes: All statistics were calculated using data for accounts in the system for December 2006. *Monthly Salary is calculated as the last recorded daily integrated wage for the worker multiplied by 365/12 and adjusted for inflation (reported in 2007 pesos). The first panel of demographic summary statistics are for the entire population with number of observations of $25,876,207,25,753,981,23,953,273$, and $25,876,217$ for gender, age, monthly salary and account balance, respectively. Statistics on system affiliation and Afore choice were calculated using a random $1 \%$ sample of account holders because calculating the characteristics of all choices for all affiliates is computationally burdensome. The sample size for these calculations is 236,572 
Table 3: Survey Sample Versus Population Characteristics

\begin{tabular}{|c|c|c|c|c|c|}
\hline Variable & & $\begin{array}{c}\text { Sample } \\
\text { Mean }\end{array}$ & $\begin{array}{c}\text { Population } \\
\text { Mean* }\end{array}$ & $\begin{array}{c}\text { Lower } \\
95 \% \text { CI }\end{array}$ & $\begin{array}{c}\text { Upper } \\
95 \% \text { CI }\end{array}$ \\
\hline \multirow{5}{*}{$\begin{array}{l}\text { Fraction Male }(\mathrm{N}=742) \\
\text { Age }(\mathrm{N}=755)\end{array}$} & & 0.644 & 0.604 & 0.569 & 0.639 \\
\hline & Fraction age $14-30$ & 0.420 & 0.313 & 0.280 & 0.346 \\
\hline & Fraction age $31-40$ & 0.338 & 0.342 & 0.309 & 0.376 \\
\hline & Fraction age $41-50$ & 0.166 & 0.198 & 0.170 & 0.227 \\
\hline & Fraction age 51 or older & 0.077 & 0.147 & 0.122 & 0.172 \\
\hline \multirow{8}{*}{$\begin{array}{l}\text { Monthly Salary } \\
(\mathrm{N}=694)\end{array}$} & Fraction 3,000 pesos or less & 0.199 & 0.258 & 0.226 & 0.291 \\
\hline & Fraction $3,001-4,500$ & 0.156 & 0.175 & 0.147 & 0.203 \\
\hline & Fraction $4,501-6,500$ & 0.163 & 0.159 & 0.132 & 0.187 \\
\hline & Fraction $6,501-10,000$ & 0.140 & 0.152 & 0.126 & 0.179 \\
\hline & Fraction $10,001-15,000$ & 0.102 & 0.101 & 0.078 & 0.123 \\
\hline & Fraction $15,001-20,000$ & 0.066 & 0.049 & 0.033 & 0.065 \\
\hline & Fraction $20,001-25,000$ & 0.040 & 0.033 & 0.020 & 0.046 \\
\hline & Fraction more than 25,000 & 0.134 & 0.072 & 0.053 & 0.091 \\
\hline \multirow{16}{*}{$\begin{array}{l}\text { Current Afore }{ }^{* *} \\
(\mathrm{~N}=615)\end{array}$} & Actinver & 0.016 & 0.008 & 0.001 & 0.016 \\
\hline & Azteca & 0.055 & 0.015 & 0.006 & 0.025 \\
\hline & Banamex & 0.198 & 0.235 & 0.202 & 0.269 \\
\hline & Bancomer & 0.120 & 0.136 & 0.109 & 0.164 \\
\hline & Banorte & 0.044 & 0.053 & 0.036 & 0.071 \\
\hline & Coppel & 0.002 & 0.001 & -0.002 & 0.004 \\
\hline & HSBC & 0.042 & 0.051 & 0.033 & 0.068 \\
\hline & Inbursa & 0.104 & 0.066 & 0.047 & 0.086 \\
\hline & ING & 0.054 & 0.069 & 0.049 & 0.089 \\
\hline & Invercap & 0.018 & 0.008 & 0.001 & 0.015 \\
\hline & IXE & 0.015 & 0.006 & 0.000 & 0.012 \\
\hline & Metlife & 0.041 & 0.011 & 0.003 & 0.019 \\
\hline & Principal & 0.028 & 0.069 & 0.049 & 0.090 \\
\hline & Profuturo & 0.112 & 0.110 & 0.086 & 0.135 \\
\hline & Santander & 0.093 & 0.109 & 0.084 & 0.134 \\
\hline & XXI & 0.059 & 0.049 & 0.032 & 0.066 \\
\hline \multirow{6}{*}{$\begin{array}{l}\text { Educational Attainment } \\
(\mathrm{N}=760)\end{array}$} & Primary or less & 0.047 & -- & -- & -- \\
\hline & Secondary & 0.162 & -- & -- & -- \\
\hline & High school & 0.266 & -- & -- & -- \\
\hline & Technical School & 0.091 & -- & -- & -- \\
\hline & College degree & 0.337 & -- & -- & -- \\
\hline & Post graduate degree & 0.097 & -- & -- & -- \\
\hline
\end{tabular}

Notes: Data from the responses to questions 1 (Male), 3 (Age), 6 (Educational Attainment), and 23 (Monthly Salary). *Population statistics calculated using SAR database snapshot for Estado de Mexico and Distrito Federal, June 2007. **To save space, market shares for Afirme Bajío, AhorraAhora, Argos, DelaGente, and Scotia were omitted. Zero respondents stated they were currently in those relatively new Afores, and zero is contained in the 95 percent confidence interval for the mean of a random sample. 
Table 4: Probit Analysis of Reasons for Afore Choice and Demographics

\begin{tabular}{|c|c|c|c|c|c|c|c|c|}
\hline & $\begin{array}{c}(1) \\
\text { Financial } \\
\text { Stability } \\
\end{array}$ & $\begin{array}{c}(2) \\
\text { Other } \\
\text { Accounts }\end{array}$ & Payroll & $\begin{array}{c}(4) \\
\text { Branch } \\
\text { Access } \\
\end{array}$ & $\begin{array}{l}(5) \\
\text { Low } \\
\text { Fees }\end{array}$ & Returns & $\begin{array}{c}(7) \\
\text { Better } \\
\text { Service } \\
\end{array}$ & $\begin{array}{c}(8) \\
\text { Brand } \\
\text { Prestige }\end{array}$ \\
\hline $\begin{array}{l}\text { Dep. Var. } \\
\text { Mean }\end{array}$ & 0.218 & 0.154 & 0.158 & 0.091 & 0.345 & 0.232 & 0.281 & 0.168 \\
\hline & $\begin{array}{c}0.086 \\
(0.137)\end{array}$ & $\begin{array}{c}0.052 \\
(0.148)\end{array}$ & $(0.14$ & $\begin{array}{l}-0.302 * \\
(0.168)\end{array}$ & $\begin{array}{l}-0.025 \\
(0.121)\end{array}$ & $\begin{array}{c}0.377^{* * * *} \\
(0.135)\end{array}$ & $\begin{array}{l}-0.078 \\
(0.125)\end{array}$ & $\begin{array}{c}0.005 \\
(0.138)\end{array}$ \\
\hline $\begin{array}{l}\text { Schooling > } \\
\text { High Schol }\end{array}$ & & $\begin{array}{c}0.047 \\
(0.150)\end{array}$ & & & $\begin{array}{l}0.237^{*} \\
(0.125)\end{array}$ & & $\begin{array}{c}0.108 \\
(0.128)\end{array}$ & $\begin{array}{c}0.158 \\
(0.143)\end{array}$ \\
\hline Male & & & & & $\begin{array}{c}0.101 \\
(0.108)\end{array}$ & & $\begin{array}{c}0.087 \\
(0.112)\end{array}$ & $\begin{array}{l}-0.018 \\
(0.122)\end{array}$ \\
\hline $\begin{array}{l}\text { Has Internet } \\
\text { Access }\end{array}$ & $\begin{array}{c}0.110 \\
(0.172)\end{array}$ & $\begin{array}{l}-0.11 \\
(0.18\end{array}$ & $\begin{array}{l}-0.158 \\
(0.167)\end{array}$ & $\begin{array}{c}-0.372 * * \\
(0.187)\end{array}$ & $\begin{array}{c}0.030 \\
(0.144)\end{array}$ & $\begin{array}{l}-0.010 \\
(0.161)\end{array}$ & $\begin{array}{c}-0.304^{* *} \\
(0.149)\end{array}$ & $\begin{array}{l}-0.135 \\
(0.164)\end{array}$ \\
\hline $\begin{array}{l}\text { Internet } \\
\text { Use Index }\end{array}$ & $\begin{array}{c}0.208^{* * * *} \\
(0.068)\end{array}$ & $\begin{array}{c}0.159^{* *} \\
(0.074)\end{array}$ & & $\begin{array}{c}0.008 \\
(0.080)\end{array}$ & $\begin{array}{l}-0.017 \\
(0.058)\end{array}$ & $\begin{array}{c}0.039 \\
(0.065)\end{array}$ & $\begin{array}{c}0.098 \\
(0.061)\end{array}$ & $\begin{array}{c}0.045 \\
(0.066)\end{array}$ \\
\hline Age & & $\begin{array}{c}0.011 \\
(0.031)\end{array}$ & $\begin{array}{l}-0.024 \\
(0.030)\end{array}$ & $\begin{array}{l}-0.002 \\
(0.036)\end{array}$ & $\begin{array}{c}0.015 \\
(0.027)\end{array}$ & $\begin{array}{l}-0.005 \\
(0.029)\end{array}$ & $\begin{array}{c}0.029 \\
(0.028)\end{array}$ & $\begin{array}{l}-0.009 \\
(0.031)\end{array}$ \\
\hline Age Squared & $\begin{array}{c}0.000 \\
(0.000)\end{array}$ & $\begin{array}{c}0.000 \\
(0.000)\end{array}$ & $\begin{array}{c}0.001 \\
(0.000)\end{array}$ & $\begin{array}{c}0.000 \\
(0.000)\end{array}$ & $\begin{array}{c}0.000 \\
(0.000)\end{array}$ & $\begin{array}{c}0.000 \\
(0.000)\end{array}$ & $\begin{array}{c}0.000 \\
(0.000)\end{array}$ & $\begin{array}{c}0.000 \\
(0.000)\end{array}$ \\
\hline Observations & 660 & 660 & 660 & 660 & 660 & 660 & 660 & 660 \\
\hline
\end{tabular}

Notes: Standard errors in parentheses. ${ }^{*}$ significant at $10 \%$ level; ** significant at $5 \%$ level; $* * *$ significant at $1 \%$ level. Each column presents results from a probit of the top stated reason for picking an Afore on demographic characteristics. Data from responses to questions $3,6,7,8,18$, and 23 of survey collected in June 2007. We exclude regressions for the following choice reasons: i) "An Salesman gave me a present to switch" had only 3\% of people who listed it as one of their top 3 choice reasons, ii) "The Afore offers voluntary contribution accounts" because $17.5 \%$ of people listed this as a choice while almost no one in the SAR actually has a voluntary account and there were no significant explanatory variables in this regression, and iii) a response of "Other". "The internet use index is the maximum response to each of the Internet usage questions in the survey. The highest value indicates that a respondent said she used the Internet frequently for either paying bills, reading the news, or making reservations. The lowest value indicates that she did not use the Internet for any of these activities. 
Table 5: Probit Analysis of Stated Sources of Information for Afore Choice

\begin{tabular}{|c|c|c|c|c|c|}
\hline $\begin{array}{l}\text { Top Information } \\
\text { Source: }\end{array}$ & $\begin{array}{c}\text { (1) } \\
\text { Family \& } \\
\text { Friends }\end{array}$ & $\begin{array}{c}\text { (2) } \\
\text { Co-workers }\end{array}$ & Employer & $\begin{array}{c}(4) \\
\text { CONSAR }\end{array}$ & $\begin{array}{c}(5) \\
\text { Agente } \\
\text { Promotor } \\
\end{array}$ \\
\hline Mean & 0.145 & 0.122 & 0.177 & 0.216 & 0.269 \\
\hline Salary $>$ Median & $\begin{array}{c}0.126 \\
(0.144)\end{array}$ & $\begin{array}{c}0.156 \\
(0.154)\end{array}$ & $\begin{array}{c}-0.315^{* *} \\
(0.140)\end{array}$ & $\begin{array}{c}0.142 \\
(0.131)\end{array}$ & $\begin{array}{c}0.021 \\
(0.122)\end{array}$ \\
\hline Schooling $>$ & -0.159 & 0.132 & 0.225 & 0.093 & 0.038 \\
\hline High School & $(0.145)$ & $(0.158)$ & $(0.143)$ & $(0.134)$ & $(0.126)$ \\
\hline Male & $\begin{array}{c}0.118 \\
(0.128)\end{array}$ & $\begin{array}{c}0.160 \\
(0.137)\end{array}$ & $\begin{array}{c}-0.324 * * * \\
(0.120)\end{array}$ & $\begin{array}{c}0.318 * * * \\
(0.118)\end{array}$ & $\begin{array}{l}-0.001 \\
(0.109)\end{array}$ \\
\hline Has Internet & 0.007 & 0.119 & -0.131 & -0.240 & -0.010 \\
\hline Access & $(0.171)$ & $(0.191)$ & $(0.165)$ & $(0.159)$ & $(0.146)$ \\
\hline Internet & $0.113^{*}$ & -0.012 & -0.001 & $0.144 * *$ & -0.049 \\
\hline Use Index $^{\dagger}$ & $(0.068)$ & $(0.073)$ & $(0.066)$ & $(0.064)$ & $(0.058)$ \\
\hline Age & $\begin{array}{c}-0.056^{*} \\
(0.030)\end{array}$ & $\begin{array}{c}0.048 \\
(0.035)\end{array}$ & $\begin{array}{l}0.054^{*} \\
(0.031)\end{array}$ & $\begin{array}{c}0.017 \\
(0.029)\end{array}$ & $\begin{array}{c}0.030 \\
(0.027)\end{array}$ \\
\hline Age Squared & $\begin{array}{c}0.001 * \\
(0.000)\end{array}$ & $\begin{array}{l}-0.001 \\
(0.000)\end{array}$ & $\begin{array}{c}0.000 \\
(0.000)\end{array}$ & $\begin{array}{c}0.000 \\
(0.000)\end{array}$ & $\begin{array}{c}0.000 \\
(0.000)\end{array}$ \\
\hline Observations & 688 & 688 & 688 & 688 & 688 \\
\hline
\end{tabular}

Notes: Standard errors in parentheses. * significant at $10 \%$ level; ** significant at $5 \%$ level; $* * *$ significant at $1 \%$ level. Each column presents results from a probit of the top stated source of information used when choosing an Afore on demographic characteristics. Data from responses to questions 3 (Age), 6 (Schooling $>$ High School), 7 Has Internet Access), 8 (Internet Use Index), 17 (Sources of Information), and 23 (Salary > Median) of survey collected in June 2007. ${ }^{\dagger}$ The internet use index is the maximum response to each of the Internet usage questions in the survey. The highest value indicates that a respondent said she used the Internet frequently for either paying bills, reading the news, or making reservations. The lowest value indicates that she did not use the Internet for any of these activities. This formula for the Internet index fits regressions better than other alternatives such as the average usage across all three activities. 
Table 6: Stated Methods of Savings

\begin{tabular}{|lcccc|}
\hline Savings Method & $\begin{array}{c}\text { \% Who Save } \\
\text { in This Way }\end{array}$ & $\begin{array}{c}\text { \% } \\
\text { Male }\end{array}$ & $\begin{array}{c}\text { \%Schooling }> \\
\text { High School }\end{array}$ & $\begin{array}{c}\text { Monthly } \\
\text { Salary }\end{array}$ \\
\hline \hline Do Not Save & $26.5 \%$ & $60.6 \%$ & $32.2 \%$ & $\$ 5,809$ \\
Save Money at Home/Informal Network* & $20.8 \%$ & $69.1 \%$ & $40.4 \%$ & $\$ 7,173$ \\
Save Money in Cooperative** & $12.7 \%$ & $67.7 \%$ & $44.2 \%$ & $\$ 8,290$ \\
Save at a Bank & $39.3 \%$ & $67.9 \%$ & $68.5 \%$ & $\$ 12,601$ \\
Save in Stocks/Bonds/Foreign Currency & $16.3 \%$ & $68.6 \%$ & $89.3 \%$ & $\$ 18,967$ \\
\hline
\end{tabular}

Notes: Data from responses to questions 1 (Male), 6 (Schooling > High School), 23 (Monthly Salary), and 23 (Savings Method) of survey collected in June 2007. *Includes Tandas. **Cooperativas, Cajas de Ahorro, Cajas Solidarias.

Table 7: Financial Literacy Index

\begin{tabular}{|c|c|c|c|c|c|}
\hline & \% Male & $\begin{array}{c}\text { \% Schooling > } \\
\text { High School } \\
\end{array}$ & $\begin{array}{l}\text { \% Saves in Bank/Stocks/ } \\
\text { Bonds/Foreign Currency }\end{array}$ & Age & $\begin{array}{c}\text { Monthly } \\
\text { Salary } \\
\end{array}$ \\
\hline \multicolumn{6}{|l|}{ Index Value: } \\
\hline Zero Correct & $52.6 \%$ & $34.5 \%$ & $32.3 \%$ & $\begin{array}{l}31.57 \\
(12.02)\end{array}$ & $\begin{array}{l}\$ 6,196 \\
(5,880)\end{array}$ \\
\hline One Correct & $65.5 \%$ & $45.7 \%$ & $41.8 \%$ & $\begin{array}{l}33.70 \\
(10.59)\end{array}$ & $\begin{array}{l}\$ 8,154 \\
(6,694)\end{array}$ \\
\hline Two Correct & $72.7 \%$ & $70.0 \%$ & $61.1 \%$ & $\begin{array}{l}33.37 \\
(10.04)\end{array}$ & $\begin{array}{l}\$ 12,510 \\
(8,991)\end{array}$ \\
\hline Three Correct & $71.2 \%$ & $83.6 \%$ & $76.4 \%$ & $\begin{array}{l}35.69 \\
(11.33)\end{array}$ & $\begin{array}{l}\$ 19,077 \\
(8,126)\end{array}$ \\
\hline
\end{tabular}

Notes: Data from responses to questions 1 (Male), 3 (Age), 6 (Schooling > High School), 23 (Monthly Salary), 25, 26, and 27 (Financial Literacy Index Value) of survey collected in June 2007. 
Table 8: Reduced Form Impact of Information Format on Fee of First-Choice Afore Dependent Variable: Fee of First-Choice Afore

(1)

(2)

\begin{tabular}{lcc|}
\hline \hline Constant & $1.702^{* * *}$ & $1.812^{* * *}$ \\
Viewed fees in pesos per year & $(0.027)$ & $(0.076)$ \\
Viewed fees in pesos over 10 years & $-0.075^{* *}$ & $-0.073^{* *}$ \\
& $(0.031)$ & $(0.033)$ \\
Median salary (in thousands of pesos) & $-0.066^{* *}$ & -0.053 \\
& $(0.031)$ & $(0.033)$ \\
Bachelor's degree or more & -- & -0.049 \\
& -- & $(0.044)$ \\
Has Internet access & -- & -0.07 \\
& -- & $(0.045)$ \\
Internet usage index & -- & 0.002 \\
& -- & $(0.051)$ \\
Age & -- & 0.007 \\
Financially literate (score $>=2)$ & -- & $0.020)$ \\
& -- & $(0.002)$ \\
Stated fees were important for Afore & -- & $-0.179 * *$ \\
choice & -- & $(0.037)$ \\
Sophisticated saving & -- & $(0.037)$ \\
(saves in equity/debt/foreign currency) & -- & -0.04 \\
Observations & -- & $(0.044)$ \\
R-squared & -- & $110 * *$ \\
Notes & -- & 0.09 \\
\hline
\end{tabular}

Notes: $*$ significant at $10 \%$;** significant at $5 \%$; *** significant at $1 \%$. Standard errors are clustered at the survey respondent level. Each column reports coefficients from an OLS regression of the fee of the first-ranked Afore on indicators for the information format the fees were presented in. Data come from sheets where only fees were presented, and the presentation of fees varied from annual percentage rates to cost in pesos per year to cost in pesos over ten years. 
Table 9: Rank-Ordered Conditional Logit Results for Stated Afore Demand

\begin{tabular}{|c|c|c|c|c|}
\hline & $(1)$ & $(2)$ & $(3)$ & $(4)$ \\
\hline Fees & $\begin{array}{c}-1.162 * * * \\
(0.348)\end{array}$ & $\begin{array}{c}-1.019 * * * \\
(0.342)\end{array}$ & $\begin{array}{c}-0.750 * * \\
(0.370)\end{array}$ & $\begin{array}{l}-0.593 \\
(0.374)\end{array}$ \\
\hline Fee* Financially literate & -- & $\begin{array}{c}-0.786^{* * * *} \\
(0.253)\end{array}$ & $\begin{array}{c}-0.791 * * * \\
(0.253)\end{array}$ & $\begin{array}{c}-1.323 * * * \\
(0.350)\end{array}$ \\
\hline Fee* Saw fees in pesos & $\begin{array}{l}-- \\
--\end{array}$ & $\begin{array}{l}-- \\
--\end{array}$ & $\begin{array}{c}-0.319^{* *} \\
(0.149)\end{array}$ & $\begin{array}{c}-0.521 * * * \\
(0.169)\end{array}$ \\
\hline Fee* Saw pesos* Financially & -- & -- & -- & $0.754 * *$ \\
\hline literate & -- & -- & -- & $(0.352)$ \\
\hline Fee* Female & $\begin{array}{l}-0.055 \\
(0.209)\end{array}$ & $\begin{array}{l}-0.105 \\
(0.211)\end{array}$ & $\begin{array}{c}-0.112 \\
(0.212)\end{array}$ & $\begin{array}{l}-0.121 \\
(0.213)\end{array}$ \\
\hline $\begin{array}{l}\text { Fee* Salary (in thousands of } \\
\text { pesos) }\end{array}$ & $\begin{array}{c}-0.035^{* *} \\
(0.017)\end{array}$ & $\begin{array}{l}-0.022 \\
(0.018)\end{array}$ & $\begin{array}{l}-0.021 \\
(0.018)\end{array}$ & $\begin{array}{l}-0.022 \\
(0.018)\end{array}$ \\
\hline Fee* Age & $\begin{array}{c}0.011 \\
(0.009)\end{array}$ & $\begin{array}{c}0.009 \\
(0.009)\end{array}$ & $\begin{array}{c}0.008 \\
(0.009)\end{array}$ & $\begin{array}{c}0.008 \\
(0.009)\end{array}$ \\
\hline Fee* Values fees & $\begin{array}{c}-0.580 * * * \\
(0.210)\end{array}$ & $\begin{array}{c}-0.584 * * * \\
(0.210)\end{array}$ & $\begin{array}{c}-0.596^{* * * *} \\
(0.210)\end{array}$ & $\begin{array}{c}-0.593 * * * \\
(0.210)\end{array}$ \\
\hline Fee* Sophisticated saving & $\begin{array}{c}0.068 \\
(0.297)\end{array}$ & $\begin{array}{c}0.177 \\
(0.298)\end{array}$ & $\begin{array}{c}0.178 \\
(0.297)\end{array}$ & $\begin{array}{c}0.158 \\
(0.298)\end{array}$ \\
\hline Fee* Bachelors degree or more & $\begin{array}{l}-0.193 \\
(0.250)\end{array}$ & $\begin{array}{l}-0.12 \\
(0.249)\end{array}$ & $\begin{array}{l}-0.127 \\
(0.250)\end{array}$ & $\begin{array}{l}-0.123 \\
(0.251)\end{array}$ \\
\hline Indicator for current (own) Afore & $\begin{array}{c}1.247 * * * \\
(0.066)\end{array}$ & $\begin{array}{c}1.241 * * * \\
(0.066)\end{array}$ & $\begin{array}{c}1.243 * * * \\
(0.066)\end{array}$ & $\begin{array}{c}1.244 * * * \\
(0.066)\end{array}$ \\
\hline Afore Actinver & $\begin{array}{c}-1.288 * * * \\
(0.185)\end{array}$ & $\begin{array}{c}-1.288 * * * \\
(0.185)\end{array}$ & $\begin{array}{c}-1.290 * * * \\
(0.185)\end{array}$ & $\begin{array}{c}-1.291 * * * \\
(0.185)\end{array}$ \\
\hline Afore Banamex & $\begin{array}{l}0.970 * * * \\
(0.117)\end{array}$ & $\begin{array}{l}0.973 * * * \\
(0.117)\end{array}$ & $\begin{array}{l}0.969 * * * \\
(0.117)\end{array}$ & $\begin{array}{c}0.970 * * * \\
(0.117)\end{array}$ \\
\hline Afore Bancomer & $\begin{array}{c}0.678 * * * \\
(0.120)\end{array}$ & $\begin{array}{c}0.677 * * * \\
(0.120)\end{array}$ & $\begin{array}{c}0.673 * * * \\
(0.120)\end{array}$ & $\begin{array}{c}0.672 * * * \\
(0.120)\end{array}$ \\
\hline Afore Coppel & $\begin{array}{c}0.334 * * * \\
(0.114)\end{array}$ & $\begin{array}{c}0.313 * * * \\
(0.114)\end{array}$ & $\begin{array}{c}0.308 * * * \\
(0.114)\end{array}$ & $\begin{array}{c}0.311^{* * * *} \\
(0.114)\end{array}$ \\
\hline Afore HSBC & $\begin{array}{c}0.776 * * * \\
(0.109)\end{array}$ & $\begin{array}{c}0.768 * * * \\
(0.108)\end{array}$ & $\begin{array}{c}0.765 * * * \\
(0.108)\end{array}$ & $\begin{array}{c}0.763 * * * \\
(0.108)\end{array}$ \\
\hline Afore IXE & $\begin{array}{c}-0.751 * * * \\
(0.181)\end{array}$ & $\begin{array}{c}-0.759 * * * \\
(0.181)\end{array}$ & $\begin{array}{c}-0.767 * * * \\
(0.182)\end{array}$ & $\begin{array}{c}-0.772 * * * \\
(0.182)\end{array}$ \\
\hline Afore Inbursa & $\begin{array}{c}0.830^{* * * *} \\
(0.109)\end{array}$ & $\begin{array}{c}0.821 * * * \\
(0.108)\end{array}$ & $\begin{array}{c}0.818 * * * \\
(0.108)\end{array}$ & $\begin{array}{c}0.813 * * * \\
(0.108)\end{array}$ \\
\hline Afore Metlife & $\begin{array}{c}0.467 * * * \\
(0.106)\end{array}$ & $\begin{array}{c}0.467 * * * \\
(0.106)\end{array}$ & $\begin{array}{c}0.461 * * * \\
(0.105)\end{array}$ & $\begin{array}{c}0.461^{* * *} \\
(0.106)\end{array}$ \\
\hline Afore Principal & $\begin{array}{c}-0.992 * * * \\
(0.196)\end{array}$ & $\begin{array}{c}-0.993 * * * \\
(0.196)\end{array}$ & $\begin{array}{c}-0.993 * * * \\
(0.196)\end{array}$ & $\begin{array}{c}-0.993 * * * \\
(0.196)\end{array}$ \\
\hline Afore XXI & $\begin{array}{c}0.310^{* *} \\
(0.127)\end{array}$ & $\begin{array}{c}0.297 * * \\
(0.127)\end{array}$ & $\begin{array}{c}0.299 * * \\
(0.127)\end{array}$ & $\begin{array}{c}0.297 * * \\
(0.127)\end{array}$ \\
\hline Afore Banorte & $\begin{array}{c}-0.316^{* *} \\
(0.138)\end{array}$ & $\begin{array}{c}-0.317 * * \\
(0.138)\end{array}$ & $\begin{array}{c}-0.320 * * \\
(0.138)\end{array}$ & $\begin{array}{c}-0.321 * * \\
(0.138)\end{array}$ \\
\hline Observations & 23426 & 23426 & 23426 & 23426 \\
\hline
\end{tabular}

Notes: * significant at $10 \% ; * *$ significant at $5 \% ; * * *$ significant at $1 \%$. Standard errors are clustered at the survey respondent level. Each column presents the results from a rank-ordered conditional logit of Afore choice on Afore and individual characteristics using responses from respondents who were given information on fees only. The fees were presented in an annual percentage rates, as costs in pesos per year, or as costs in pesos over ten years. Fixed effects estimates for Afirme Bajio, Azteca, ING, Invercap, and Santander were statistically indistinguishable from Profuturo GNP (the excluded Afore). 
Table 10: Reduced-Form Impact of Information on Fee of the First-Choice Afore

\begin{tabular}{|c|c|c|}
\hline $\begin{array}{l}\text { Dependant Variable: } \\
\text { Fee of the First-Choice Afore }\end{array}$ & (1) & (2) \\
\hline Constant & $\begin{array}{l}1.687 * * * \\
(0.029)\end{array}$ & $\begin{array}{l}1.753 * * * \\
(0.078)\end{array}$ \\
\hline Viewed fees in pesos per year & $\begin{array}{l}-0.054 * \\
(0.031)\end{array}$ & $\begin{array}{l}-0.070 * * \\
(0.034)\end{array}$ \\
\hline Viewed fees and returns in pesos & $\begin{array}{l}0.106 * * \\
(0.051)\end{array}$ & $\begin{array}{c}0.085 \\
(0.065)\end{array}$ \\
\hline Viewed 1 year returns & $\begin{array}{c}0.291 * * * \\
(0.043)\end{array}$ & $\begin{array}{c}0.291 * * * \\
(0.052)\end{array}$ \\
\hline Viewed 3 year returns & $\begin{array}{l}0.212 * * * \\
(0.043)\end{array}$ & $\begin{array}{l}0.225 * * * \\
(0.053)\end{array}$ \\
\hline Median salary (in thousands of pesos) & -- & $\begin{array}{c}0.000 \\
(0.044)\end{array}$ \\
\hline Bachelor's degree or more & $\begin{array}{l}-- \\
--\end{array}$ & $\begin{array}{l}-0.043 \\
(0.045)\end{array}$ \\
\hline Has Internet access & $\begin{array}{l}-- \\
--\end{array}$ & $\begin{array}{c}0.035 \\
(0.054)\end{array}$ \\
\hline Internet usage index & $\begin{array}{l}-- \\
--\end{array}$ & $\begin{array}{l}-0.007 \\
(0.022)\end{array}$ \\
\hline Age & $\begin{array}{l}-- \\
--\end{array}$ & $\begin{array}{c}0.000 \\
(0.002)\end{array}$ \\
\hline Financially literate (score $>=2$ ) & $\begin{array}{l}-- \\
--\end{array}$ & $\begin{array}{c}-0.118 * * * \\
(0.039)\end{array}$ \\
\hline Fees as top reason for choosing Afore & $\begin{array}{l}-- \\
--\end{array}$ & $\begin{array}{l}-0.081 * * \\
(0.039)\end{array}$ \\
\hline Returns as top reason for choosing Afore & -- & $\begin{array}{c}0.038 \\
(0.044)\end{array}$ \\
\hline Sophisticated saving (saves in equity/debt/foreign currency) & $\begin{array}{l}-- \\
--\end{array}$ & $\begin{array}{c}0.022 \\
(0.047)\end{array}$ \\
\hline $\begin{array}{l}\text { Observations } \\
\text { R-squared }\end{array}$ & $\begin{array}{c}2290 \\
0.06\end{array}$ & $\begin{array}{c}2033 \\
0.1\end{array}$ \\
\hline
\end{tabular}

Notes: * significant at $10 \%$;* significant at 5\%; *** significant at $1 \%$. Standard errors are clustered at the survey respondent level. Each column reports coefficients from an OLS regression of the fee of the first-ranked Afore on indicators for the information format the fees were presented in. Data are from sheets where both fees and returns were presented, and the presentation of fees and returns was either as an annual percentage rate or in pesos per year. 
Table 11: Rank-Ordered Logit Model of Afore Choice

\begin{tabular}{|lcccc|}
\hline & $\mathbf{( 1 )}$ & $\mathbf{( 3 )}$ & $\mathbf{( 2 )}$ & $\mathbf{( 4 )}$ \\
\hline \hline Fees & $-0.370^{* * *}$ & $-0.298^{* * *}$ & $-0.178^{* *}$ & -0.161 \\
& $(0.074)$ & $(0.112)$ & $(0.084)$ & $(0.127)$ \\
1 year returns & $0.138^{* * *}$ & $0.050^{* *}$ & $0.067^{* * *}$ & 0.011 \\
& $(0.019)$ & $(0.022)$ & $(0.022)$ & $(0.025)$ \\
3 year returns & -- & $0.172^{* * *}$ & -- & $0.096^{* *}$ \\
& -- & $(0.038)$ & -- & $(0.043)$ \\
Fees* Financially literate (score>=2) & -- & -- & $-0.703^{* * *}$ & $-0.383^{* *}$ \\
& -- & -- & $(0.154)$ & $(0.186)$ \\
1 year returns* Financially literate & -- & -- & $0.225^{* * *}$ & $0.112^{* * *}$ \\
(score>=2) & -- & -- & $(0.038)$ & $(0.042)$ \\
3 years returns* financially & -- & -- & -- & $0.215^{* * *}$ \\
literate (score $>=2)$ & -- & -- & -- & $(0.074)$ \\
Indicator for current (own) Afore & $1.142^{* * *}$ & $1.192^{* * *}$ & $1.109^{* * *}$ & $1.199^{* * *}$ \\
& $(0.087)$ & $(0.084)$ & $(0.089)$ & $(0.085)$ \\
& & & & \\
Afore fixed effects & $\mathrm{Y}$ & $\mathrm{Y}$ & $\mathrm{Y}$ & $\mathrm{Y}$ \\
& & & & \\
Observations & 8262 & 8228 & 8245 & 8211 \\
Number of groups & 486 & 484 & 485 & 483 \\
\hline
\end{tabular}

Notes: * significant at $10 \% ; * *$ significant at $5 \% ; * * *$ significant at $1 \%$. Standard errors are clustered at the survey respondent level. Each column presents the results from a rank-ordered conditional logit of Afore choice on Afore and individual characteristics using responses from respondents who were given information on fees and past returns, and the information was presented in an annual percentage rate or as cost in pesos per year. 
Table 12: Demand Elasticities for Afores

\begin{tabular}{|lccccc|c|}
\hline Afore & $\mathbf{( 1 )}$ & $\mathbf{( 2 )}$ & $\mathbf{( 3 )}$ & $\mathbf{( 4 )}$ & $\mathbf{( 5 )}$ & $\mathbf{( 6 )}$ \\
\hline \hline Actinver & -1.712 & -2.358 & -3.384 & -0.954 & -0.543 & -0.427 \\
Afirme Bajío & -1.451 & -1.820 & -2.546 & -0.679 & -0.656 & -0.358 \\
Azteca & -1.542 & -2.024 & -2.851 & -0.673 & -0.304 & -0.432 \\
Banamex & -1.662 & -2.576 & -3.885 & -0.774 & -0.575 & -0.516 \\
Bancomer & -1.645 & -2.486 & -3.697 & -0.847 & -0.510 & -0.555 \\
Banorte Generali & -1.679 & -2.372 & -3.403 & -1.123 & -0.634 & -0.634 \\
Coppel & -1.515 & -1.943 & -2.634 & -0.852 & -0.484 & -0.523 \\
HSBC & -1.578 & -2.228 & -3.120 & -0.796 & -0.592 & -0.637 \\
ING & -1.856 & -2.825 & -4.090 & -1.068 & -0.553 & -0.624 \\
IXE & -1.676 & -2.283 & -3.152 & -0.892 & -0.747 & -0.427 \\
Inbursa & -1.500 & -1.978 & -2.802 & -0.932 & -0.404 & -0.313 \\
Invercap & -1.715 & -2.386 & -3.244 & -1.300 & -0.413 & -0.444 \\
Metlife & -1.492 & -1.937 & -2.654 & -0.596 & -0.702 & -0.526 \\
Principal & -1.797 & -2.638 & -3.742 & -1.148 & -0.583 & -0.720 \\
Profuturo GNP & -1.717 & -2.472 & -3.563 & -0.888 & -0.555 & -0.620 \\
Santander & -1.732 & -2.615 & -3.881 & -0.885 & -0.580 & -0.682 \\
XXI & -1.619 & -2.226 & -3.127 & -0.914 & -0.740 & -0.526 \\
\hline
\end{tabular}

Notes: Column 1 calculates demand elasticities for specification 4 in Table 13, assuming nobody receives information in pesos format. Column 2 calculates demand elasticities for specification 4 in Table 13 assuming that all people view information in pesos instead of in percentages. Column 3 instead assumes that all people are financially literate, but nobody receives information in pesos. Column 4 calculates demand elasticities using responses in which agents viewed 1 year past returns only, allowing for full interactions between responsiveness to returns and responsiveness to fees with baseline demographic characteristics. Column 5 uses estimates with full demographic interactions from responses in which people viewed both 1 and 3 year past returns. Column 6 attempts to compare these elasticities to the demand elasticity for the respondent at the approximate time they chose their stated Afore. We create the choice set based on the number of years the person states they have been with their afore, choosing the midpoint of the time period they selected. Then we estimate a conditional logit model based on the fees and returns the Afores charged at that point in time. We then convert this into a demand elasticity facing each firm. 